\title{
ВІДТВОРЮВАЛЬНІ ЯКОСТІ СВИНОМАТОК ЗАЛЕЖНО ВІД СИСТЕМ МІКРОКЛІМАТУ ВПРОДОВЖ РОКУ
}

\author{
Жижка Станіслав Васильович \\ аспірант \\ Сумський національний аграрний університет \\ ORCID: 0000-0001-9645-8013 / AAH-3617-2019 \\ E-mail: dust.delacrua@gmail.com \\ Повод Микола Григорович \\ доктор сільськогосподарських наук, професор \\ Сумський національний аграрний університет \\ ORCID: 0000-0001-9272-9672/ W-1565-2018 \\ E-mail: nic.pov@ukr.net.
}

\begin{abstract}
Вивчено результати впливу геотермальної та традиційної системи вентилювання приміщень для утримання холостих і умовно поросних свиноматок на параметри мікроклімату в них впродовж року, та залежність від цих параметрів відтворних якостей свиноматок. Як класична так і геотермальна системи вентилювання приміщень забезпечили оптимальний мікроклімат в них у перехідні пори року, але не забезпечили рекомендованих показників температури повітря і його вологості в зимову та літню пори року. Різниця в температурі повітря та лігва не спричинила різниці в температурі поверхні шкіри свиноматок в усі пори року за винятком зимової. Геотермальна система вентилювання приміщення за рахунок стабілізації повітря в підземних шахтах, та більш рівномірного його розподілу за допомогою повітропроводів, створювала більш комфортні температурні умови утримання для свиноматок під час осіменіння, що в подальшому мало вплив на відтворювальні якості та продуктивні показники свиноматок в усі пори року за винятком зими. Параметри мікроклімату створені різними системами вентилювання приміщення впливали на прихід свиноматок в охоту, їх запліднюваність та відсоток опоросу. Більш відчутним цей вплив був влітку та восени, а меншим взимку та навесні. Мікроклімат в приміщеннях для утримання холостих і умовно поросних свиноматок виявив деякий вплив на відтворювальні якості свиноматок. Дослідження в даному напрямку планується продовжити, а їх результати використовувати при проектуванні та реконструкції свинарських приміщень.
\end{abstract}

Ключові слова: вентиляція, мікроклімат, повітря, температура, газовий склад, вологість, свиноматка, порося, багатоплідність, приріст, збереженість.

DOI: https://doi.org/10.32845/bsnau.lvst.2019.4.12

Сучасне виробництво продукції свинарства базується на індустріальних технологіях, що передбачають створення оптимального мікроклімату, незалежно від кліматичних параметрів зовнішнього середовища, які змінюються як впродовж року так і впродовж доби [5, 7]. Від вибору системи створення мікроклімату залежать не тільки комфорт утримання тварин, але й ї продуктивні показники, адже чим більше енергії буде витрачено на подолання несприятливих факторів, тим менше її буде витрачено на продуктивні показники [3]. В залежності від параметрів навколишнього середовища в різні пори року [6, 8, 9], різні системи створення мікроклімату по-різному забезпечують ці параметри середовищі існування тварин [1, 2]. У зв'язку з цим, проблема вибору системи створення мікроклімату при будівництві нових або реконструкції свинарських приміщень $є$ актуальною і має практичне та теоретичне значення [4].

Матеріали та методи досліджень. Матеріалом для досліджень слугували помісні свиноматки, отримані від схрещування порід ландрас $\times$ велика біла ірландського походження та кнурів синтетичної термінальної лінії «MaxGrow», ірландської компанії Hermitage Genetics осіменіння яких проводилось в цехах за двох різних систем регулювання мікроклімату - традиційної та геотермальної. Для вивчення впливу систем створення мікроклімату на репродуктивні функції свиноматок, нами було проведено дослідження на базі репродукторної ферми приватного підприємства «Сігма» в с. Степове Дніпропетровського району Дніпропетровської області з червня 2016 р. по грудень 2017. Для

дослідження було відібрано, за методом пар аналогів, в кожну календарну пору року, по 150 голів дорослих (3-4го циклу) свиноматок. Відбір тварин для дослідження проводився з врахуванням віку, маси, та попередньої продуктивносTi.

Умови годівлі були ідентичними для всіх тварин, яка здійснювалась сухими, повноцінним комбікормами власного виробництва і була повноцінною, збалансованою.

Для осіменіння свиноматок використовувалась сперма одних і тих же кнурів в усі пори року. Виявлення охоти проводилось за допомогою кнура-пробника два рази на добу, о 6:30 та о 13:30. Осіменіння проводилось 3 допомогою одноразових катетерів два рази на добу: після виявлення та повторно через 24 години.

Тварини контрольної групи під час холостого та умовно-поросного періоду були розміщені в приміщенні з вентиляцією негативного тиску (традиційною системою), повітрообмін при якій забезпечується витяжними шахтними даховими вентиляторами та припливними клапанами, рівномірно встановленими на стінних приміщення. Їх аналоги 3 дослідної групи утримувалась також у приміщенні з вентиляцією негативного тиску, але в якій руху повітря здійснюється через підземні повітропроводи та рівномірно розподіляється за рахунок перфорованих повітропроводів розташованих над станками. За такого типу вентилювання повітря, проходить по підземних тунелях і в холодну пору отримує тепло від ґрунту, а в жарку пору віддає його за рахунок стабільної температури в заглиблених повітропроводах. 
Упродовж всього періоду дослідження, кожного тижня, в станках проводились заміри параметрів мікроклімату за загальноприйнятими методиками.

Вимірювання температури лігва у кожному із станків здійснювалось за допомогою пірометра Testo 805, також ним були отримані показники температури шкіри свиноматки та поросят в трьох точках - з лівої сторони на лопатці, на животі, та окості, виміри параметрів мікроклімату проводилось в семи різних точках станка. Для визначення показника температури повітря та швидкості його руху використовувався термоанемометр Testo 425м. Вміст вуглекислого газу $\left(\mathrm{CO}_{2}\right)$, аміаку $\left(\mathrm{NH}_{3}\right)$, сірководню $\left(\mathrm{H}_{2} \mathrm{~S}\right)$ - визначався за допомогою газоаналізатора «ДОЗОР-С-М». Вологість повітря, за допомогою термогідрометру Testo 605, на рівні лежання поросят (7 cм), їх стояння (25 см) та на рівні дихальних шляхів дорослої людини (160) см. Виміри проводили вдень та зранку - два рази на добу. УЗД сканування свиноматок проводилось за допомогою ультразвукового сканеру Agroscan A16.

Аналіз відтворювальних якостей свиноматок проводився за наступними показниками: \% приходу в охоту (як відношення свиноматок що прийшли в охоту після відлучення поросят до загальної кількості відлучених свиноматок), \% запліднених свиноматок (як відношення свиноматок з підтвердженою за допомогою УЗД поросністю до кількості осімененних), \% (відносна частка) опоросу (як кількість свиноматок що опоросилися до кількості свиноматок з підтвердженою поросністю).

Після підтвердження поросності за допомогою УЗД сканування, свиноматок обох груп утримували в одному приміщенні з традиційною системою створення мікроклімату, групами по 10-12 голів на повністю щілинній підлозі.

На 110 день поросності їх переводили в приміщення для опоросу з традиційною системою вентиляції де проводили аналіз продуктивності за показниками: багатоплідність, великоплідність та маса гнізда новонароджених поросят, кількість, збереженість, індивідуальна жива маса та маса гнізда поросят при відлученні.

Результати досліджень. Результати проведених досліджень, наведених у табл. 1, свідчать про те, що взимку температура повітря в зоні життєдіяльності свиноматки була вірогідно $(p<0,01)$ вищою на $3,3^{\circ} \mathrm{C}$ в дослідному приміщенні порівняно $з$ контрольним, та знаходилась в межах норм ВНТП-АПК-02.05. («Свинарські підприємства (комплекси, ферми, малі ферми)». Тоді як температура в контрольному знаходилась на відмітці в $14,5^{\circ} \mathrm{C}$, що нижче рекомендованих норм на 1,5 . Також, суттєво на $2,7^{\circ} \mathrm{C}$ нижчою $(p<0,05)$ в цьом свинарнику, виявилась температура суцільної бетонної підлоги в зоні лежання свиноматки, водночас температура решітчастої бетонної підлоги в ній була на $3,8^{\circ} \mathrm{C}$ $(p<0,05)$ нижчою порівняно 3 аналогічними показниками дослідного приміщення. Ці фактори спричинили тенденцію до зниження на $1,5^{\circ} \mathrm{C}$ температури шкіри у свиноматок контрольної групи в порівнянні з дослідною.

Також геотермальна система вентиляції змогла забезпечити оптимальну швидкість руху повітря - 0,12 м/с $(p<0,01)$, тоді як при традиційній системі цей показник становив $0,23 \mathrm{~m} / \mathrm{c}$.

Незважаючи на досить високу відносну вологість повітря зовні приміщення в цю пору року - $86,2 \%$, в обох підконтрольних приміщеннях її показник знаходився в межах рекомендованих норм. Але при цьому, в свинарнику з геотермальною вентиляцією, спостерігалось її вірогідне зниження на $8,7 \%(p<0,01)$.

Обидві системи створення мікроклімату забезпечили оптимальні показники вмісту аміаку та сірководню в повітрі приміщення, але не змогли забезпечити оптимальний склад вуглекислого газу, його показник перевищував максимально допустиму концентрацію на 0,08\% об в обох приміщеннях.

Таблиця 1

Параметри навколишнього середовища та мікроклімату в приміщеннях для утримання холостих і умовно поросних свиноматок за різної системи їх підтримання в зимову пору року

\begin{tabular}{|c|c|c|c|}
\hline \multirow{2}{*}{ Показник } & \multirow{2}{*}{$\begin{array}{c}\text { Норми (ВНТП- } \\
\text { АПК-02.05.) }\end{array}$} & \multicolumn{2}{|c|}{ Тип вентиляції } \\
\hline & & традиційна & геотермальна \\
\hline Група свиноматок & & І контрольна & II дослідна \\
\hline Температура повітря зовні приміщення, ${ }^{\circ} \mathrm{C}$ & - & \multicolumn{2}{|c|}{$-1,5$} \\
\hline Відносна вологість повітря, зовні приміщення, \% & - & \multicolumn{2}{|c|}{86,2} \\
\hline Швидкість руху повітря, зовні приміщення, м/с & - & \multicolumn{2}{|c|}{2,63} \\
\hline Атмосферний тиск, мм. рт. ст. & - & \multicolumn{2}{|c|}{767,1} \\
\hline Температура повітря у зоні життєдіяльності свиноматки, ${ }^{\circ} \mathrm{C}$ : & $16-20$ & $14,5 \pm 1,41$ & $17,8 \pm 0,82^{*}$ \\
\hline Температура шкіри свиноматки, ${ }^{\circ} \mathrm{C}$ & & $22,6 \pm 2,02$ & $24,1 \pm 2,76$ \\
\hline Температура суцільної бетонної підлоги, C & - & $15,0 \pm 1,01$ & $17,7 \pm 0,81^{*}$ \\
\hline Температура щілинної бетонної підлоги, C & - & $14,3 \pm 1,46$ & $18,1 \pm 1,11^{*}$ \\
\hline Відносна вологість повітря, \% & $40-70$ & $66,5 \pm 1,6$ & $60,7 \pm 1,32^{* *}$ \\
\hline Швидкість руху повітря, м/с & 0,30 & $0,23 \pm 0,021$ & $0,12 \pm 0,036^{* \star}$ \\
\hline \multicolumn{4}{|l|}{ Вміст в повітрі приміщень: } \\
\hline $\mathrm{CO}_{2}, \%$ об & 0,20 & $0,28 \pm 0,066$ & $0,28 \pm 0,036$ \\
\hline $\mathrm{NH}_{3}, \mathrm{Mr} / \mathrm{M}^{3}$ & 20 & $3,7 \pm 0,66$ & $5,8 \pm 0,8^{*}$ \\
\hline $\mathrm{H}_{2} \mathrm{~S}, \mathrm{Mr} / \mathrm{M}^{3}$ & 10 & $0,6 \pm 0,67$ & $1,6 \pm 1,39$ \\
\hline
\end{tabular}

Примітка -* $(p<0,05) ;$;* $^{\prime}(p<0,01) ;$

Навесні, як видно з табл. 2, жодна з систем створення мікроклімату не змогла забезпечити оптимальну вологість повітря: $79,2 \%$ в контрольному приміщенні, та 75,1\% в дослідному. При цьому, в приміщенні з геотермаль- ною вентиляцією, де утримувались свині дослідної групи, вона була нижчою на $5,2 \%(p<0,01)$, що в дану пору року створювало більш комфортні умови для тварин. Аналогічна тенденція спостерігалась і з швидкістю руху повітря. За 
традиційної системи вентилювання приміщень не було досягнуто оптимального показника, тоді як в дослідному свинарнику швидкість його руху була вірогідно $(p<0,001)$ нижчою на 51,9\% за рахунок більш рівномірного його розподілу перфорованими каналами і знаходилась в межах допустимих норм. Вміст газів $\mathrm{CO}_{2}, \mathrm{NH}_{3}$ та $\mathrm{H}_{2} \mathrm{~S}$ в обох приміщеннях знаходився в межах гранично допустимих концентрацій, але за геотермальної системи був вірогідно вищим: сірководню на $1,1 \mathrm{~m} / \mathrm{M}^{3}$ ( $\left.p<0,001\right)$, аміаку на $2,4 \mathrm{~m} / \mathrm{m}^{3}$ $(p<0,001)$, та вуглекислого газу на $0,02 \%$ об. $(p<0,05)$. Тем- пература повітря у зоні життєдіяльності свиноматки в контрольному приміщенні становила $19,4^{\circ} \mathrm{C}$, тоді як в дослідному цей показник дещо перевищував норму $-20,6^{\circ} \mathrm{C}$, та був вірогідно ( $<<0,001)$ вищим від контрольного. Вищими порівняно з зимою виявились показники температури як суцільної так і решітчастої бетонної підлоги в обох свинарниках, і майже не залежали від типу вентиляції приміщень. Зменшення різниці в температурі повітря та підлоги в контрольному і дослідному свинарнику спричинило майже рівну температуру на поверхні шкіри свиноматок.

Таблиця 2

Параметри навколишнього середовища та мікроклімату в приміщеннях для утримання холостих і умовно поросних свиноматок за різної системи їх підтримання в весняну пору року

\begin{tabular}{|c|c|c|c|}
\hline \multirow{2}{*}{ Показник } & \multirow{2}{*}{$\begin{array}{c}\text { Норми (ВНТП- } \\
\text { АПК-02.05.) }\end{array}$} & \multicolumn{2}{|c|}{ Тип вентиляції } \\
\hline & & традиційна & геотермальна \\
\hline Група свиноматок & & І контрольна & ІІ дослідна \\
\hline Температура повітря зовні приміщення, ${ }^{\circ} \mathrm{C}$ & - & \multicolumn{2}{|c|}{$+11,1$} \\
\hline Відносна вологість повітря, зовні приміщення, \% & - & \multicolumn{2}{|c|}{62,0} \\
\hline Швидкість руху повітря, зовні приміщення, м/с & - & \multicolumn{2}{|c|}{4,33} \\
\hline Атмосферний тиск, мм. рт. ст. & - & \multicolumn{2}{|c|}{767,1} \\
\hline Температура повітря у зоні життєдіяльності свиноматки, ${ }^{\circ} \mathrm{C}$ : & 16-20 & $19,4 \pm 0,23$ & $20,6 \pm 0,35^{* *}$ \\
\hline Температура шкіри свиноматки, ${ }^{\circ} \mathrm{C}$ & - & $25,9 \pm 0,49$ & $26,2 \pm 0,57$ \\
\hline Температура суцільної бетонної підлоги, C & - & $19,6 \pm 0,88$ & $19,4 \pm 0,94$ \\
\hline Температура щілинної бетонної підлоги, C & - & $19,2 \pm 0,45$ & $19,5 \pm 0,67$ \\
\hline Відносна вологість повітря, \% & $40-70$ & $79,2 \pm 1,15$ & $75,1 \pm 1,01^{* *}$ \\
\hline Швидкість руху повітря, м/с & 0,30 & $0,54 \pm 0,021$ & $0,26 \pm 0,039^{* * *}$ \\
\hline \multicolumn{4}{|l|}{ Вміст в повітрі приміщень: } \\
\hline $\mathrm{CO}_{2}, \%$ об & $0,20-0,40$ & $0,17 \pm 0,006$ & $0,19 \pm 0,009^{*}$ \\
\hline $\mathrm{NH}_{3}, \mathrm{Mr} / \mathrm{M}^{3}$ & 20 & $5,2 \pm 0,21$ & $7,6 \pm 0,20^{* * *}$ \\
\hline $\mathrm{H}_{2} \mathrm{~S}, \mathrm{Mr} / \mathrm{M}^{3}$ & 10 & $1,2 \pm 0,23$ & $2,3 \pm 0,17^{\star * *}$ \\
\hline
\end{tabular}

Примітка - ${ }^{*}(p<0,05) ; *(p<0,01) ; *(p<0,001) ;$

В літню пору року (табл.3), як традиційна, так і геотермальна системи вентилювання приміщень забезпечували оптимальний газовий склад повітря, та підтримували його в межах гранично допустимих концентрацій. Температура повітря у зоні життєдіяльності свиноматки перевищувала норму в обох групах, але за геотермальної системи була вірогідно (p<0,001), на 3,0 $\mathrm{C}$, або $11,1 \%$ нижчою. Температура суцільної частини бетонної підлоги в лігві свиноматки була вищою на $3,2^{\circ} \mathrm{C}$, або $12,2 \%(p<0,01)$ за класичної схеми вентиляції порівняно з геотермальною. Також в цьому приміщені виявлено вищу на 2,2, або 8,4\% (p<0,001) температуру перфорованої бетонної підлоги.

Таблиця 3

Параметри навколишнього середовища та мікроклімату

\section{в приміщеннях для утримання холостих і умовно поросних свиноматок} за різної системи їх підтримання в літню пору року

\begin{tabular}{|c|c|c|c|}
\hline \multirow{2}{*}{ Показник } & \multirow{2}{*}{$\begin{array}{c}\text { Норми (ВНТП- } \\
\text { АПК-02.05.) }\end{array}$} & \multicolumn{2}{|c|}{ Тип вентиляції } \\
\hline & & традиційна & геотермальна \\
\hline Група свиноматок & & I контрольна & II дослідна \\
\hline Температура повітря зовні приміщення, ${ }^{\circ} \mathrm{C}$ & - & \multicolumn{2}{|c|}{25,4} \\
\hline Відносна вологість повітря, зовні приміщення, \% & - & \multicolumn{2}{|c|}{58,7} \\
\hline Швидкість руху повітря, зовні приміщення, м/с & - & \multicolumn{2}{|c|}{3,15} \\
\hline Атмосфрерний тиск, мм. рт. ст. & - & \multicolumn{2}{|c|}{755,6} \\
\hline Температура повітря у зоні життєдіяльності свиноматки, ${ }^{\circ} \mathrm{C}$ : & $16-20$ & $27,1 \pm 1,02$ & $24,1 \pm 0,24^{* *}$ \\
\hline Температура шкіри свиноматки, ${ }^{\circ} \mathrm{C}$ & - & $32,4 \pm 0,61$ & $32,6 \pm 0,34$ \\
\hline Температура суцільної бетонної підлоги, C & - & $26,3 \pm 0,85$ & $23,1 \pm 0,76^{* *}$ \\
\hline Температура щілинної бетонної підлоги, C & - & $26,3 \pm 0,48$ & $24,1 \pm 0,46^{* * *}$ \\
\hline Відносна вологість повітря, \% & $40-70$ & $28,9 \pm 2,73$ & $32,6 \pm 0,41^{* *}$ \\
\hline Швидкість руху повітря, м/с & 1,0 & $1,17 \pm 0,084$ & $0,93 \pm 0,079^{*}$ \\
\hline \multicolumn{4}{|l|}{ Вміст в повітрі приміщень: } \\
\hline $\mathrm{CO}_{2}, \%$ об & 0,20 & $0,06 \pm 0,032$ & $0,04 \pm 0,003$ \\
\hline $\mathrm{NH}_{3}, \mathrm{Mr} / \mathrm{M}^{3}$ & 20 & $0,6 \pm 0,88$ & $0,3 \pm 0,22$ \\
\hline $\mathrm{H}_{2} \mathrm{~S}, \mathrm{Mr} / \mathrm{M}^{3}$ & 10 & $0,5 \pm 0,32$ & $0,4 \pm 0,20$ \\
\hline
\end{tabular}

Примітка -*(p<0,05);" $(p<0,01) ; "(p<0,001) ;$

Не дивлячись на істотну різницю в температурі навколишнього середовища температура шкіри свиноматки суттєво не відрізнялась в розрізі груп.

За рахунок досить сухого повітря зовні приміщення,

Вісник Сумського національного аграрного університету 
відносна його вологість всередині, як контрольного так і дослідного свинарника була нижче рекомендованих ВНТПАПК-02.05 норм. Але за геотермальної системи цей показник був вірогідно на $3,7 \%(p<0,01)$ вище порівняно з традиційною системою вентилювання, але виявився нижчим від рекомендованої ВНТП норми на 7,4\%, тоді як при традиційній системи вентиляції ця різниця становила $11,1 \%$.

Швидкість руху повітря в контрольній групі перевищувала норму на 0,17 м/с, тоді як в дослідній знаходилась в іiі межах та була нижчою від контрольної на 0,24 м/с $(p<0,05)$.

В осінню пору року (табл. 4), за рахунок спекотної іï частини, температура в обох приміщеннях знаходилась в межах $17,9-20,6^{\circ} \mathrm{C}$, що близько до верхньої межі рекомендованих ВНТП норм. Вірогідно $(p<0,05)$ вищою на $2,7{ }^{\circ} \mathrm{C}$ вона була в свинарнику з традиційною системою вентиляції. Температура підлоги в лігві свиноматок обох груп суттєво не відрізнялись. Водночас в свинарнику з класичною вентиляцією спостерігалась тенденція до більш рівномірної температури обох частин бетонної підлоги, тоді як в дослідному свинарнику різниця між температурою суцільної та перфорованої підлоги склала $3,9^{\circ} \mathrm{C}$. Як навесні і влітку не виявлено практичної різниці між температурою шкіряного покрову свиноматок обох груп.

Відносна вологість повітря також була вірогідно $(p<0,05)$ нижчою в свинарнику де утримувались тварини дослідної групи - 66,3\%, в порівнянні 3 приміщенням де знаходились тварини контрольної групи - 72,3\%. Швидкість руху повітря в обох приміщеннях залежала від конструктивних особливостей системи вентиляції, але знаходилась в межах норми і склала в приміщенні 3 геотермальною системою вентиляції - 0,10 м/с, тоді як дослідному приміщенні вона виявилась вищою на $0,26 \mathrm{~m} / \mathrm{c}(\mathrm{p}<0,001)$ порівняно 3 контрольним.

Таблиця 4

Параметри навколишнього середовища та мікроклімату в приміщеннях для утримання холостих і умовно поросних свиноматок за різної системи їх підтримання в осінню пору року

\begin{tabular}{|c|c|c|c|}
\hline \multirow{2}{*}{ Показник } & \multirow{2}{*}{$\begin{array}{c}\text { Норми (ВНТП- } \\
\text { АПК-02.05.) }\end{array}$} & \multicolumn{2}{|c|}{ Тип вентиляції } \\
\hline & & традиційна & геотермальна \\
\hline Група свиноматок & & І контрольна & II дослідна \\
\hline Температура повітря зовні приміщення, ${ }^{\circ} \mathrm{C}$ & - & \multicolumn{2}{|c|}{12,1} \\
\hline Відносна вологість повітря, зовні приміщення, \% & - & \multicolumn{2}{|c|}{73,6} \\
\hline Швидкість руху повітря, зовні приміщення, м/с & - & \multicolumn{2}{|c|}{3,34} \\
\hline Атмосферний тиск, мм. рт. ст. & - & \multicolumn{2}{|c|}{764,4} \\
\hline Температура повітря у зоні життєдіяльності свиноматки, ${ }^{\circ} \mathrm{C}:$ & $16-20$ & $20,6 \pm 1,02$ & $17,9 \pm 0,81^{*}$ \\
\hline Температура шкіри свиноматки, ${ }^{\circ} \mathrm{C}$ & - & $28,9 \pm 0,52$ & $28,6 \pm 1,30$ \\
\hline Температура суцільної бетонної підлоги, C & - & $18,9 \pm 1,20$ & $20,8 \pm 2,76$ \\
\hline Температура щілинної бетонної підлоги, C & - & $19,1 \pm 0,91$ & $16,9 \pm 1,38$ \\
\hline Відносна вологість повітря, \% & $40-70$ & $72,3 \pm 1,47$ & $66,3 \pm 2,41^{*}$ \\
\hline Швидкість руху повітря, м/с & 0,30 & $0,36 \pm 0,25$ & $0,10 \pm 0,053^{* * *}$ \\
\hline \multicolumn{4}{|l|}{ Вміст в повітрі приміщень: } \\
\hline $\mathrm{CO}_{2,} \%$ об & 0,20 & $0,10 \pm 0,013$ & $0,11 \pm 0,024$ \\
\hline $\mathrm{NH}_{3}, \mathrm{Mr} / \mathrm{M}^{3}$ & 20 & $2,1 \pm 1,64$ & $4,4 \pm 2,97$ \\
\hline $\mathrm{H}_{2} \mathrm{~S}, \mathrm{Mr} / \mathrm{M}^{3}$ & 10 & $0,4 \pm 0,4$ & $0,5 \pm 0,30$ \\
\hline
\end{tabular}

Примітка -* $(p<0,05) ; "(p<0,01) ; ;^{* *+}(p<0,001) ;$

За результатами проведеного аналізу показників відтворювальних якостей свиноматок, що утримувались в холостий та умовно-поросний період в приміщеннях за різної системи створення мікроклімату, (табл. 5), слід відмі- тити значну їх залежність від систем створення мікроклімату в літню та перехідні пори року, тоді як взимку не встановлено вірогідної залежності.

Відтворювальні показники свиноматок що утримувались в холостий та умовно-поросний період за різних систем створення мікроклімату у приміщенні впродовж року

\begin{tabular}{|c|c|c|c|c|c|c|c|c|}
\hline \multirow[b]{2}{*}{ Показник } & \multicolumn{2}{|c|}{ Зима } & \multicolumn{2}{|c|}{ Весна } & \multicolumn{2}{|c|}{ Літо } & \multicolumn{2}{|c|}{ Осінь } \\
\hline & 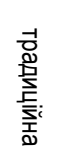 & 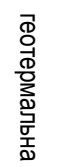 & 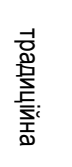 & 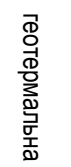 & 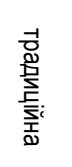 & 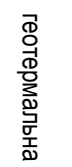 & 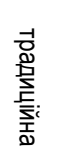 & 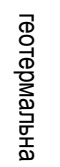 \\
\hline Частка приходу в охоту після відлучення,\% & 91,3 & 91,9 & 93,1 & 92,5 & 84,4 & 90,0 & 87,5 & 92,5 \\
\hline Кількість осіменених свиноматок, гол. & 150 & 150 & 150 & 150 & 150 & 150 & 150 & 150 \\
\hline Кількість свиноматок з підтвердженою поросністю, гол & 122 & 120 & 118 & 131 & 118 & 126 & 122 & 127 \\
\hline Частка запліднених свиноматок, \% & 81,3 & 80,0 & 78,7 & 87,3 & 78,7 & 84,0 & 81,3 & 84,7 \\
\hline Вибракувано свиноматок за час умовно поросного періоду, гол & 4 & 5 & 5 & 5 & 8 & 5 & 7 & 5 \\
\hline Частка вибракуваних свиноматок до УЗД - 35, \% & 2,7 & 3,3 & 3,3 & 3,3 & 5,3 & 3,3 & 4,7 & 3,3 \\
\hline Кількість свиноматок що опоросились, гол & 108 & 107 & 104 & 115 & 102 & 110 & 107 & 114 \\
\hline Частка опоросу, \% & 88,5 & 91,2 & 88,1 & 87,8 & 86,4 & 87,3 & 87,7 & 89,8 \\
\hline
\end{tabular}

Більш комфортні умови створені геотермальною системою вентиляції посприяли кращому приходу в охоту свиноматок дослідної групи в спекотні літні, та осінні місяці. Так, еструс краще проявлявся у свиноматок дослідної групи 
влітку на 5,6\% та восени на 5,0\%, тоді як взимку і навесні такої розбіжності в частці виявлених в охоті свиноматок не спостерігалось.

Запліднюваність свиноматок також залежала від мікроклімату в приміщеннях створюваного різними системами ïх вентилювання. 3 березня по травень, за рахунок більш сприятливого мікроклімату в середині дослідного приміщення суттєво з на 8,6\% збільшилася частка плідно осіменених свиноматок, тоді як влітку ця різниця склала 5,3, а восени $3,4 \%$.

Взимку частка плідно осіменених свиноматок виявилась на 1,3\% вищою у приміщенні з традиційною вентиляці$€ ю$.

Деяка різниця спостерігалась і за кількістю вибувших впродовж холостого і умовно поросного періоду тварин. Взимку та навесні частка свиноматок, що вибули була приблизно рівною в обох приміщеннях. Тоді як влітку вона булла меншою на 2,0\% а восени на1,4\% в дослідному приміщенні.

Співвідношення кількості свиноматок що опоросились до їх кількості з позитивним тестом на поросність, в усі пори року виявилось кращим у тварин дослідної групи, які утримувались в холостий і умовно поросний період в приміщенні з геотермальною вентиляцією. Так встановлено, що частка опоросу у тварин дослідної групи була кращою на 2,7\% за осіменіння їх взимку, на 0,3\% навесні, 2,1\% восени і на 0,9\% влітку

Тобто, параметри мікроклімату, що створені різними системами вентилювання приміщення впливали на прихід свиноматок в охоту, їх запліднюваність та відсоток опоросу. Більш відчутним цей вплив був влітку та восени, а меншим взимку та навесні.

Створені умови утримання за яких проводилось осіменіння свиноматок та їх утримання в умовно поросний період (табл. 6) певною мірою вплинули на потенціал їх продуктивності під час опоросу і підсисного періоду. Також, на наш погляд, ці показники залежали від пори року на яку приходився опорос. Так, не встановлено різниці за більшістю відтворювальних показників у свиноматок які осіменялись та утримувались в період умовної поросності взимку в приміщеннях за різних систем створення мікроклімату. Винятком $€$ збереженість поросят, яка виявилась вірогідно $(p<0,05)$ на $0,82 \%$ вищою в гніздах свиноматок дослідної групи.

Таблиця 6

Продуктивні показники свиноматок що утримувались в холостий та умовно-поросний період за різних систем створення мікроклімату у приміщенні впродовж року

\begin{tabular}{|c|c|c|c|c|}
\hline \multirow{2}{*}{ Показник } & \multirow{2}{*}{$\frac{\mid \text { контрольна }}{\bar{X} \pm S \bar{x}}$} & \multirow{2}{*}{$\frac{\text { I дослідна }}{\bar{X} \pm S \bar{x}}$} & \multicolumn{2}{|c|}{$\begin{array}{c} \pm \text { традиційна до } \\
\text { геотермальної }\end{array}$} \\
\hline & & & абсолютна & $\%$ \\
\hline \multicolumn{5}{|c|}{ Зимова пора року утримання в цеху холостих і поросних свиноматок (весняний опорос) } \\
\hline Багатоплідність, гол. & $11,60 \pm 0,162$ & $11,66 \pm 0,128$ & $-0,06$ & 0,5 \\
\hline Маса гнізда при народжені, кг & $16,59 \pm 0,193$ & $16,44 \pm 0,211$ & 0,15 & 0,9 \\
\hline Великоплідність, кг & $1,43 \pm 0,019$ & $1,41 \pm 0,021$ & 0,02 & 1,4 \\
\hline Кількість поросят при відлученні, гол. & $10,75 \pm 0,115$ & $10,71 \pm 0,218$ & 0,04 & 0,4 \\
\hline Збереженість, \% & $92,67 \pm 0,312$ & $91,85 \pm 0,213^{*}$ & 0,82 & 0,9 \\
\hline Маса одного поросяти при відлученні, кг & $7,39 \pm 0,119$ & $7,41 \pm 0,095$ & $-0,02$ & 0,3 \\
\hline Маса гнізда поросят при відлучені, кг & $79,52 \pm 1,748$ & $79,36 \pm 1,236$ & 0,16 & 0,2 \\
\hline \multicolumn{5}{|c|}{ Весняна пора року утримання в цеху холостих і поросних свиноматок (літній опорос) } \\
\hline Багатоплідність, гол. & $11,89 \pm 0,113$ & $11,86 \pm 0,098$ & 0,03 & 0,3 \\
\hline Маса гнізда при народжені, кг & $16,53 \pm 0,128$ & $16,96 \pm 0,102^{* *}$ & $-0,43$ & 2,6 \\
\hline Великоплідність, кг & $1,39 \pm 0,012$ & $1,43 \pm 0,011^{*}$ & $-0,04$ & 2,9 \\
\hline Кількість поросят при відлученні, гол. & $10,73 \pm 0,142$ & $10,76 \pm 0,121$ & $-0,03$ & 0,3 \\
\hline Збереженість, \% & $90,24 \pm 0,193$ & $90,73 \pm 0,156^{*}$ & $-0,49$ & 0,5 \\
\hline Маса одного поросяти при відлученні, кг & $7,12 \pm 0,151$ & $7,16 \pm 0,100$ & $-0,04$ & 0,5 \\
\hline Маса гнізда поросят при відлучені, кг & $76,4 \pm 2,349$ & $77,04 \pm 1,954$ & $-0,64$ & 0,8 \\
\hline \multicolumn{5}{|c|}{ Літня пора року утримання в цеху холостих і поросних свиноматок (осінній опорос) } \\
\hline Багатоплідність, гол. & $11,20 \pm 0,089$ & $11,53 \pm 0,065^{\star *}$ & $-0,33$ & 3,0 \\
\hline Маса гнізда при народжені, кг & $14,45 \pm 0,096$ & $15,45 \pm 0,103^{* \star *}$ & $-1,00$ & 6,9 \\
\hline Великоплідність, кг & $1,29 \pm 0,015$ & $1,34 \pm 0,026$ & $-0,05$ & 3,9 \\
\hline Кількість поросят при відлученні, гол. & $10,39 \pm 0,150$ & $10,73 \pm 0,128$ & $-0,34$ & 3,27 \\
\hline Збереженість, \% & $92,77 \pm 0,208$ & $93,06 \pm 0,454$ & $-0,29$ & 0,31 \\
\hline Маса одного поросяти при відлученні, кг & $7,59 \pm 0,071$ & $7,53 \pm 0,080$ & 0,06 & 0,79 \\
\hline Маса гнізда поросят при відлучені, кг & $78,86 \pm 1,555$ & $80,80 \pm 1,076$ & 1,94 & 2,46 \\
\hline \multicolumn{5}{|c|}{ Осіння пора року утримання в цеху холостих і поросних свиноматок (зимовий опорос) } \\
\hline Багатоплідність, гол. & $11,20 \pm 0,156$ & $11,74 \pm 0,131^{* *}$ & $-0,54$ & 4,8 \\
\hline Маса гнізда при народжені, кг & $14,22 \pm 0,13$ & $16,08 \pm 0,36^{* \star *}$ & $-1,86$ & 13,1 \\
\hline Великоплідність, кг & $1,27 \pm 0,020$ & $1,37 \pm 0,013^{* \star \star}$ & $-0,1$ & 7,9 \\
\hline Кількість поросят при відлученні, гол. & $10,40 \pm 0,142$ & $10,92 \pm 0,204^{*}$ & $-0,52$ & 5,0 \\
\hline Збереженість, \% & $92,86 \pm 0,205$ & $93,02 \pm 0,318$ & $-0,16$ & 0,2 \\
\hline Маса одного поросяти при відлученні, кг & $7,87 \pm 0,147$ & $7,96 \pm 0,087$ & $-0,09$ & 1,1 \\
\hline Маса гнізда поросят при відлучені, кг & $82,00 \pm 2,272$ & $86,92 \pm 0,902^{*}$ & $-4,92$ & 6,0 \\
\hline
\end{tabular}

Літній опорос свиноматок, які осіменялись і утримувались в першу третину поросності навесні, мав дещо інші результати. Свиноматки дослідної групи мали вірогідно $(p>0,05)$ на 0,04 кг або на 2,9\% вищу великоплідність, що

Вісник Сумського національного аграрного університету 
сприяло збільшенню на 0,43 кг (2,6\%) маси їх гнізда при народженні ( $>>0,01)$. Також у них встановлено кращу на $0,49 \%$ збереженість ( $>>0,05)$ за загального її зниження порівняно з опоросами в попередню пору року. Також в літній період опоросу спостерігалась тенденція до зниження маси гнізда, та індивідуальної маси гнізда при відлученні, порівняно з весняними опоросами.

При осінніх опоросах свиноматок, які осіменялись та утримувались підчас умовної поросності влітку, встановлені суттєві розбіжності в розрізі груп за багатоплідністю ( $p>0,01)$ на 0,33 поросяти (3,0\%), та масою гнізда поросят при народженні на 1,0 кг або 6,9\% (p>0,001). Також у свиноматок цієі групи простежувалась тенденція до підвищення великоплідності на 3,9\%, збереженості до 0,29\%, кількості поросят при відлученні на 3,27\% та маси гнізда в цей період на 2,46\%, тоді як за масою одного поросяти в цей період різниці майже не спостерігалось.

Зимовий опорос свиноматок які осіменялись і утримувались до УЗД сканування восени, виявив суттєві переваги у свиноматок дослідної групи за багатоплідністю 0,54 голови, або 4,8\% (p>0,001) , великоплідністю 7,9\% або 0,10 кг ( $>0,001)$, що в свою чергу забезпечило їх перевагу за масою гнізда поросят при народженні 1,86 кг або 13,1\% ( $>>0,001)$, кількістю поросят при відлученні на 0,52 голови
$(5,0 \%)(p>0,05)$, та масою гнізда поросят в цей період на 4,92 кг або 6,0\% (р>0,05). Також спостерігалась тенденція до збільшення у них збереженості на 0,16\% та індивідуальної маси поросят при відлучені на 1,1\%.

В цілому, восени всі показники відтворювальної здатності свиноматок були вищими в порівнянні з попередніми порами року в які проходили опороси.

Висновки. Як класична так і геотермальна системи вентилювання приміщень забезпечили оптимальний мікроклімат в них у перехідні пори року, але не забезпечили рекомендованих показників температури повітря ф його вологості в зимову та літню пори року

Різниця в температурі повітря та лігва не спричинила різниці в температурі поверхні шкіри свиноматок в усі пори року за винятком зимової.

Параметри мікроклімату створені різними системами вентилювання приміщення впливали на прихід свиноматок в охоту,їх запліднюваність та відсоток опоросу. Більш відчутним цей вплив був влітку та восени, а меншим взимку та навесні.

Мікроклімат в приміщеннях для утримання холостих і умовно поросних свиноматок виявив деякий вплив на відтворювальні якості свиноматок.

\section{Список використаної літератури:}

1. Бальников А.А., Рябцева С.В. Влияние сезона осеменения на репродуктивные качества свиноматок. Farm Animals. 2014. №3 (7). C.50-52

2. Волощук В.М., Повод М.Г. Вплив умов утримання на репродуктивні якості свиноматок. Свинарство. Міжвідомчий тематичній збірник Інституту свинарства і АПВ НААН. Полтава. 2013. Вип. 62. С.27-32 C. $30-32$

3. Калинин. М. Оптимальный микроклимат с минимальными затратами энергоресурсов. Свиноводство. 2017. № 3.

4. Кузьмина Т.Н. Совершенствование системы микроклимата в свиноводстве. Наука в центральной России. 2014. №3 (9). С.29-36

5. Лихач В. Я. Вплив технології утримання на відтворювальні якості свиноматок. Вісник Дніпропетровського державного аграрно-економічного університету. 2015. № 4. С. 103-107

6. Походня Г.С., Ивченко А.Н., Федорчук Е.Г. Воспроизводительная функция свиноматок по сезонам года. Вестник Брянской государственной сельскохозяйственной академии. 2015. Вип. 2-1. С.44-45.

7. Пригодін А. Мікроклімат тваринницьких приміщень і його вплив на здоров'я та продуктивність тварин у ЗАТ «Бахмутський Аграрний Союз». Ветеринарна медицина України. 2004. №11. С. 42.

8. Стародубець О. О. Вплив сезону року на відтворювальні якості свиноматок. Вісник аграрної науки Причорномор'я. 2015. Вип. 4. Т. 2 С.100-103.

9. Топчій Л. І. Вплив сезонності на відтворювальні якості свиноматок української степової білої породи свиней. Науковий вісник «АсканіяНова». 2009. Вип. 2. С. 158-159.

24.Pohodnja, G.S., Kornienko, P.P., Malahova, T.A,. Kreneva, T.V. and Mamenko A.M., 2017. Jeffektivnost' vyrashhivanija porosjat pri razlichnyh srokah ih otjoma [The effectiveness of growing pigs at different periods of weaning]. Problemi zooinzheneriï ta veterinarnoï medicini. issue 33(1), pp. 129-134.

\section{References:}

1. Bal'nykov A.A., Rjabceva S.V., 2014. Vlyjanye sezona osemenenyja na reproduktyvnbe kachestva svynomatok [Influence of season insemination on reproductive qualities of sows]. Farm Animals. issue 3(7). pp.50-52.

2. Voloshhuk V. M., Povod M. G., 2013. Vplyv umov utrymannja na reproduktyvni jakosti svynomatok [The influence of keeping conditions on reproductive traits of sows]. Svynarstvo. Mizhvidomchyj tematychnij zbirnyk Instytutu svynarstva i APV NAAN. Poltava. issue 62. pp.27-32.

3. Kalynyn M. 2017. Optymal'nuj mykroklymat s mynymal'numy zatratamy energoresursov [Optimum microclimate with minimal energy costs]. Svynovodstvo. issue 3. pp.30-32.

4. Kuz'myna T.N. 2014. Sovershenstvovanye systemy mykroklymata v svynovodstve [Improving the microclimate system in pig farming]. Nauka $v$ central'noj Rossyy. issue 3 (9). pp.29-36.

5. Lyhach V.J. Lyhach A.V. 2015. Vplyv tehnologii' utrymannja na vidtvorjuval'ni jakosti svynomatok [The influence of retention technology on the reproductive quality of sows]. Visnyk Dnipropetrovs'kogo derzhavnogo agrarno-ekonomichnogo universytetu. issue 4. pp.103-107.

6. Pohodnja G.S., Yvchenko A.N., Fedorchuk E.G. 2015. Vosproyzvodytel'naja funkcyja svynomatok po sezonam goda 
[Reproductive function of sows by season]. Vestnyk Brjanskoj gosudarstvennoj sel'skohozjajstvennoj akademyy. issue 2-1. pp.44-45.

7. Prygodin A. 2004. Mikroklimat tvarynnyc'kyh prymishhen' i jogo vplyv na zdorov'ja ta produktyvnist' tvaryn u ZAT «Bahmuts'kyj Agrarnyj Sojuz» [The microclimate of livestock buildings and its impact on health and productivity of animals in JSC "Bahmutskiy Agrarian Union"]. Veterynarna medycyna Ukrai'ny. issue 11. - pp.42.

8. Starodubec' O. O. 2015. Vplyv sezonu roku na vidtvorjuval'ni jakosti svynomatok [Influence of seasonality on reproductive sows qualities] Visnyk agrarnoi' nauky Prychornomor'ja. issue. 4-2 pp.100-103.

9. Topchij L. I. 2009. Vplyv sezonnosti na vidtvorjuval'ni jakosti svynomatok ukrai'ns'koi' stepovoi' biloi' porody svynej [Influence of seasonality on reproductive sows qualities of Large White breed] Naukovyj visnyk „AskanijaNova”. issue 2. pp.158-159.

\section{Zhyzhka S. V.,}

\section{Povod N. G.}

Depending reproductive qualities of sows of the microclimate systems during the year

We have studied the results of the influence of geothermal and traditional ventilation systems for keeping sows and conditionally sowed sows on their microclimate parameters during the year, and the dependence on these parameters of sows' reproductive qualities. Both classic and geothermal indoor ventilation systems provided optimal microclimate in the transitional seasons, but did not provide the recommended indicators of air temperature and humidity in winter and summer seasons. The difference in air temperature did not affect the difference in sow skin temperature in all seasons except winter. The geothermal ventilation system created more comfortable holding conditions for sows during insemination, which affected the reproductive qualities of sows throughout the seasons except winter. The microclimate parameters created by different ventilation systems influenced the sows' arrival in hunting, their fertilization and the percentage of farrowing. This effect was more pronounced in summer and autumn, and less so in winter and spring. The research in this area is planned to be continued, and their results will be used in the design and reconstruction of pig premises.

Key words: ventilation, microclimate, air, temperature, gas composition, humidity, sow, pig, multiplicity, growth, safety.

Дата надходження до редакції: 19.10.2019 р. 